\title{
Gill net and long-line catch comparisons in a hake fishery: the case of southern Portugal*
}

\author{
MIGUEL N. SANTOS, MIGUEL B. GASPAR, CARLOS C. MONTEIRO \\ and PAULO VASCONCELOS \\ Instituto de Investigação das Pescas e do Mar (IPIMAR), Centro Regional de Investigação Pesqueira do Sul (CRIPSul), \\ Avenida 5 de Outubro s/n, P-8700-305 Olhão, Portugal. E-mail: mnsantos@ipimar.ualg.pt
}

\begin{abstract}
SUMMARY: During 1998, a study of the European hake (Merluccius merluccius) static gear fishery was undertaken in southern Portugal. This study aimed to compare long-line and gill net catches within the same area in terms of catch composition, fishing yield, by-catch and discards, and specifically for hake, catch size frequency distribution and quality of the fished product. At least 35 species of fish and invertebrates were caught, with hake dominating the catches in terms of both weight and number. The by-catch represented $23 \%$ and $15 \%$ of the catch in weight for long-lines and gill nets respectively. No illegal sized hake (under $27 \mathrm{~cm}$ total length) were caught in either gear during the study period. Discards of non-commercial species were similar for both gears and considered to be negligible $(<3 \%$ by weight). Hake discards were significantly different between gears ( $7 \%$ for long-lines and $42 \%$ for gill nets, by weight), due to fish deterioration related to soaking time. Higher daily yields were obtained for long-lines $(258.37 \mathrm{~kg} / 9,000$ hooks) compared with those for gill nets (127.12 kg / $10 \mathrm{~km}$ net). These findings will help to improve the management and conservation of this valuable hake fishery.
\end{abstract}

Key words: European hake, Merluccius merluccius, long-line, gill net, fishing yield, by-catch, discards, southern Portugal.

RESUMEN: COMPARACIONES DE LAS CAPTURAS DE LAS REDES DE ENMALLE Y PALANGRE EN UNA PESQUERÍA DE MERLUZA: EL CASO DEl SUR DE PORTUGal. - Durante 1998 se realizó un estudio de la pesquería estática de merluza europea (Merluccius merluccius) en el sur de Portugal. Este estudio estuvo dirigido a comparar las capturas de las redes de enmalle y del palangre dentro de la misma área, en términos de composición, rendimiento pesquero, captura secundaria y descartes. Específicamente para la merluza, se comparó además la distribución de frecuencias de talla y calidad del producto pescado. Se capturaron, por lo menos 35 especies de peces e invertebrados, con la merluza como especie dominante en las capturas, tanto en peso como en número. Las capturas colaterales representaron el $23 \%$ y $15 \%$ del total de la captura en peso para los palangres y redes de enmalle respectivamente. Durante el periodo de estudio no se capturaron merluzas de talla ilegal (menos de $27 \mathrm{~cm}$ de talla total) en ninguna de las artes de pesca. Los descartes de especies no comerciales fueron similares para ambas artes de pesca y se consideraron insignificantes $(<3 \%$ en peso). Los descartes de merluza fueron significativamente distintos entre artes de pesca (7\% y $42 \%$ en peso para palangre y redes de enmalle respectivamente), debido al deterioro de los peces relacionado con el tiempo de permanencia de las artes de pesca en el agua. Se obtuvieron rendimientos diarios más altos para los palangres $(258.37 \mathrm{~kg} / 9,000$ anzuelos) que para las redes de enmalle $(127.12 \mathrm{~kg} / 10 \mathrm{~km} \mathrm{de}$ red). Estos resultados contribuyen a mejorar la gestión y conservación de esta valiosa pesquería de merluza.

Palabras clave: merluza europea, Merluccius merluccius, palangre, redes de enmalle, rendimiento pesquero, captura secundaria, descartes, sur de Portugal.

\section{INTRODUCTION}

Hakes constitute a group of species with an internationally wide commercial importance (Alheit and

\footnotetext{
*Received December 10, 2001. Accepted March 25, 2002.
}

Pitcher, 1995). The European hake (Merluccius merluccius L, 1758) is one of the most important commercial demersal species in Europe (Aldebert and Carries, 1988; Martin, 1991; Oliver and Massuti, 1995). It is widely distributed in the northeastern Atlantic, Mediterranean and Black Sea (Casey and 
Pereiro, 1995). Its bathymetric range extends from shallow waters to about 1,000 metres depth, but it is most common at depths of 100-300 m (Moreira, 1987; Sanches, 1992).

Deep-water long-line and gill net fisheries targeting hake exist in a number of European countries, such as Portugal, Spain, France, England, Italy and Greece. In the Iberian region hake is the major demersal resource (FAO, 1997). According to ICES (2001), the hake total catches for 1999 in this region amounted to 7,500 metric tons (Mt). Among these hake catches, a total of $222.3 \mathrm{Mt}$ were caught by trawlers and $460.6 \mathrm{Mt}$ by gill nets and long-lines off the Algarve coast, accounting for approximately 0.7 and 2.0 million euros respectively (DGPA, 2000).

European hake was traditionally fished by longliners, but the development of the fishing industry greatly increased the use of trawling and gill netting in hake fisheries, because they require less manpower than long-lines and are operated all year-round. In general, the operating procedures of the deep-water long-line and gill net fisheries targeting hake in other European countries, namely Spain, France, England, Italy and Greece (Cardénas et al., 1987; Aldebert et al., 1993; Brabant et al., 1994; Martos and Peralta, 1995; Papaconstantinou and Stergiou, 1995; Anon., 1998; Sousa et al., 1999), are similar to those used in the Algarve. The main differences are the gear characteristics: mesh size and net height for gill nets, and diameter of the monofilament, snood length, and hook model and size for the long-lines. The long-line fishery is the most demanding of all local European artisanal fisheries. Although haulers are used to lift the gear, the remaining operations, from baiting, gear setting and retrieving, to preparing the long-line for the next set are all manual. Furthermore, due to the gear size and distance to the fishing grounds, the trips off the Algarve coast are very long, ranging from 15 to 20 hours of practically non-stop work.

The increase in fishing effort led to a decrease in the hake stock levels (ICES, 2001) and created conflicts among users of the hake fishing grounds. Locally the number of long-liners targeting hake has decreased steadily in recent years and Erzini et al. (2000) suggested that this may be due to the abovementioned reasons and a number of other factors, including catch decrease, variable prices and existence of alternative fisheries (e.g. octopus fishery).

Despite the fact that several studies have been conducted on multi-gear fisheries, namely on the comparison of static gear selectivity (Erzini et al. 1996; Huse et al., 1996, 1999, 2000) and on their performance (Aldebert et al., 1993; Nedreaas et al., 1993; Walsh, 1997), the present study constitutes an additional attempt to improve the available information on a set gear deep-water hake fishery within European waters. The main objective of this study was to compare long-line and gill net catches. This comparison includes the analysis of catch composition, fishing yield, by-catch and discards; and specifically for hake, catch size frequency distribution and quality of the fished product.

\section{MATERIAL AND METHODS}

\section{Set gear specifications and fishing regime}

In February and March 1998, professional hake fishermen were interviewed to characterise the static gears used in the deep-water hake fishery off the Algarve coast (southern Portugal). The set gear specifications are presented in Tables 1 and 2 .

TABLE 1. - Specifications of the commercial gill nets used in the Algarve hake fishery. PA - polyamide; PE - polyethylene; F - free bolsh; $\mathrm{O}$ - bolsh with float.

\begin{tabular}{|c|c|}
\hline \multicolumn{2}{|l|}{ Net yarn } \\
\hline Material & PA mono-filament \\
\hline Diameter & $0.3 \mathrm{~mm}$ \\
\hline Stretched mesh size & $81 \mathrm{~mm}$ \\
\hline Panel height (No. meshes) & 77.5 \\
\hline Panel length (No. meshes) & 1260 \\
\hline \multicolumn{2}{|l|}{ Bolsh twin } \\
\hline Material & Twisted PE \\
\hline Diameter & $1.2 \mathrm{~mm}$ \\
\hline \multicolumn{2}{|l|}{ Float rope } \\
\hline Material & Twisted PE \\
\hline Diameter & $14 \mathrm{~mm}$ \\
\hline Length & $50.61 \mathrm{~m}$ \\
\hline No. bolshes & 210 \\
\hline Bolsh size & $0.241 \mathrm{~m}$ \\
\hline Bolsh twin length & $0.271 \mathrm{~m} \times 2$ \\
\hline No. meshes per bolsh & 6 \\
\hline Hanging ratio & 0.496 \\
\hline \multicolumn{2}{|l|}{ Floats } \\
\hline Material & PVC \\
\hline Size & $60 \mathrm{~mm} 109 \mathrm{~mm}$ \\
\hline No. floats & 25 \\
\hline Floatation & $\pm 93 \mathrm{gf}$ \\
\hline Float sequence & $9 \mathrm{~F}+2 \overline{5}(1 \mathrm{O} 7 \mathrm{~F})+1 \mathrm{~F}$ \\
\hline \multicolumn{2}{|l|}{ Lead rope } \\
\hline Material & Twisted PE \\
\hline Diameter & $12 \mathrm{~mm}$ \\
\hline Length & $52.92 \mathrm{~m}$ \\
\hline No. bolshes & 210 \\
\hline Bolsh size & $0.252 \mathrm{~m}$ \\
\hline Bolsh twin length & $0.230 \mathrm{~m} \times 2$ \\
\hline No. meshes per bolsh & 6 \\
\hline Lead weight & $\pm 190 \mathrm{~g} / \mathrm{m}$ \\
\hline Hanging ratio & 0.519 \\
\hline
\end{tabular}


TABLE 2. - Specifications of the commercial long-lines used in the Algarve hake fishery. PA - polyamide; PE - polyethylene.

\begin{tabular}{|c|c|}
\hline \multicolumn{2}{|l|}{ Lift line } \\
\hline Material & Twisted PE \\
\hline Diameter & $4 \mathrm{~mm}$ \\
\hline Length & $650 \mathrm{~m}$ \\
\hline No. lines & 1/each 3 main lines \\
\hline \multicolumn{2}{|c|}{ Floats at lift line } \\
\hline Type & Bidon \\
\hline Material & Zinc plate \\
\hline Height & $0.4 \mathrm{~m}$ \\
\hline Diameter & $0.275 \mathrm{~m}$ \\
\hline \multicolumn{2}{|l|}{ Main line } \\
\hline Material & PA mono-filament \\
\hline Diameter & $1.7 \mathrm{~mm}$ \\
\hline Length & $292.2 \mathrm{~m}$ \\
\hline No. snoods & 150 \\
\hline \multicolumn{2}{|c|}{ Floats at main line } \\
\hline Type & Sphere \\
\hline Material & Glass \\
\hline Diameter & $0.09-0.1 \mathrm{~m}$ \\
\hline \multicolumn{2}{|l|}{ Snoods } \\
\hline Material & PA mono-filament \\
\hline Diameter & $0.9 \mathrm{~mm}$ \\
\hline Length & $1.2 \mathrm{~m}$ \\
\hline \multicolumn{2}{|l|}{ Hooks } \\
\hline Type & Eyed \\
\hline Material & Iron covered with inox \\
\hline Height & $38.57 \mathrm{~mm}$ \\
\hline Width & $14.94 \mathrm{~mm}$ \\
\hline \multicolumn{2}{|l|}{ Weights } \\
\hline Type & Cube \\
\hline Material & Quarry rock \\
\hline Weight & $\pm 350 \mathrm{~g}$ \\
\hline Size & $7 \times 7 \times 7 \mathrm{~cm}$ \\
\hline
\end{tabular}

The maximum length of commercial gill nets allowed by Portuguese legislation depends on the boat gross tonnage (GRT), and in the case of boats targeting hake, up to $10 \mathrm{~km}$ of gill nets (about 220 panels) can be used at one time. These gill nets are set on the seabed with the current and parallel to the coastline before sunset and retrieved 10 to 12 hours later. The retrieving operation is made using a powered net hauler and lasts from 6 to 12 hours, depending on weather conditions and the size of catch.

There is currently no legislation concerning the length of the main lines or the number of hooks each fisherman can use on a long-line. The interviews showed that the number of hooks per boat varied between 5,000 and 10,500 (but usually around 9,000 hooks). The long-lines used in the hake fishery in Algarve coastal waters are semi-pelagic ("pedrabola"), consisting of a main line with snoods directly attached at regular intervals. A loop is made at the end of each snood, which is passed through the eye of a hook baited with frozen sardine (Sardina pilchardus) strips. The long-line is kept off the seabed by a glass buoy ("bola") at intervals of 50 hooks, and weighted down with small rocks ("pedras") in between. The equipment is anchored in position by rocks, and surface floats ("bóias") are attached to the main line at intervals of 450 hooks. The gear is stored in plastic tubs with cork rims.

The long-line is set in a "zig-zag" pattern, starting one hour before sunrise (5:00 - 6:00 a.m.) and taking approximately 2 hours to complete. Immediately after setting, the gear is lifted using a hydraulic hauler, starting at the first hooks set. The retrieving operation takes 8 to 12 hours, depending on the weather conditions and the size of the catch, typically corresponding to fishing trips of a total of 15 to 20 hours.

\section{Experimental design}

The fishing surveys were carried in 1998, between May and September (the traditional period of operation for the long-line fishery), in an area well known among fishermen due to the high abundance of hake, "Beirinha" (Fig. 1) (ICES sub-area IXa). A total of 33 fishing trials were made (20 with gill nets and 13 with long-lines) with standard gears at depths ranging from 500 to 700 metres. The fishing trials were made within the same area and 26 out of the 33 were made simultaneously.

The initial idea was to use commercial boats, but due to the lack of co-operation from the commercial gill net fleet, we were obliged to set gill nets using the IPIMAR's "RV DONAX", which is operated by a professional fishermen crew. This vessel could operate with only 60 net panels. Different start times of gear retrieval were used to investigate the effect of soak time on the catches, corresponding to periods ranging from 7 to 12 hours between beginning of setting and the end of retrieval. The long-line gear was operated by the professional crew of the commercial fishing boat "TODOS IRMÃOS" (fibreglass hull: total length $=11.7 \mathrm{~m}$, GRT $=14.4$; engine power $=77 \mathrm{~kW}$ ). The number of hooks used varied between 9,000 and 10,500.

\section{Data analysis}

All fish caught by both gears were identified, measured to the centimetre below and weighted. Fish identification was made according to Albuquerque (1956), Roper et al. (1984), Whitehead et 


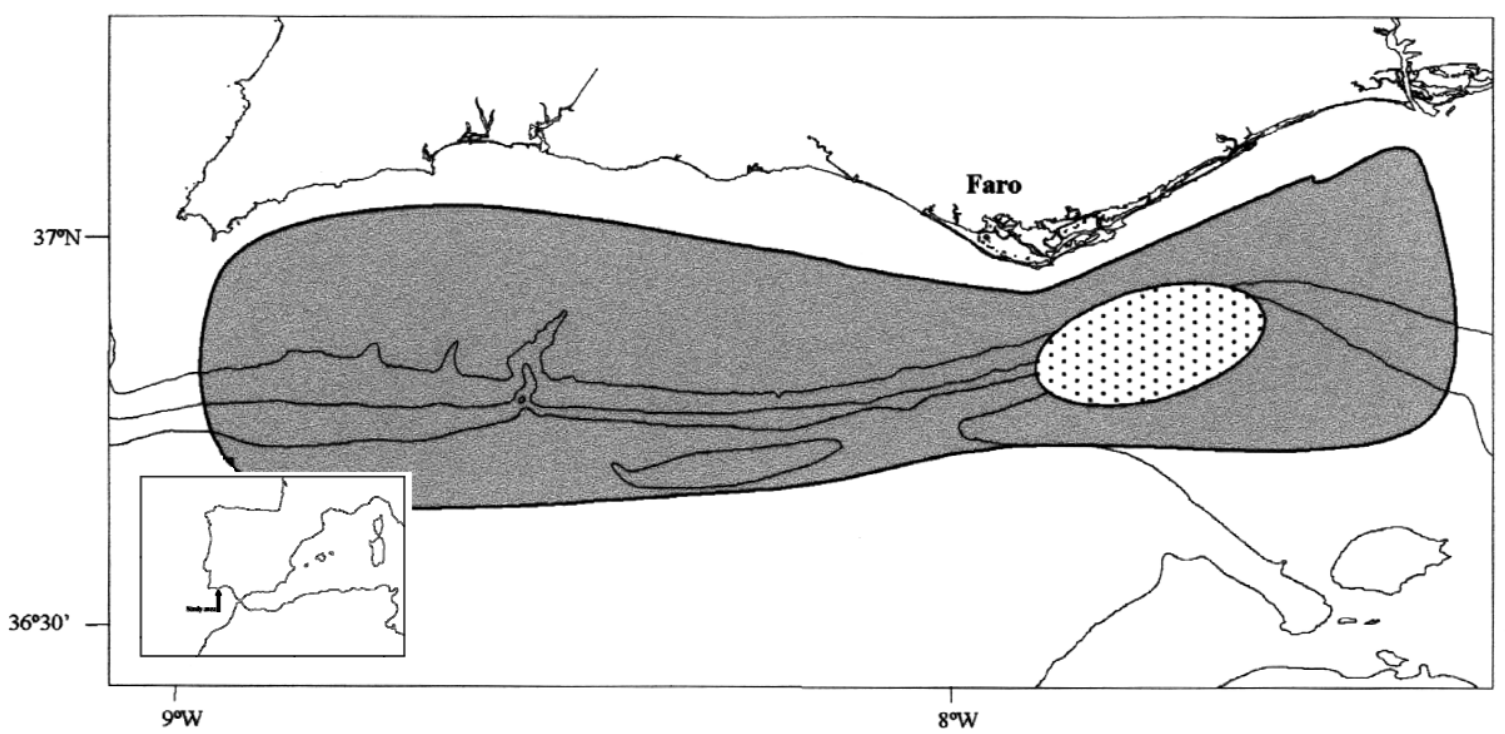

FIG. 1. - Geographical location of the Algarve coast (Southern Portugal), with particular emphasis on the "Beirinha" zone. Shaded area - hake fishing zone off the southern coast of Portugal; Dashed area - study area ("Beirinha" zone).

al. (1986) and Saldanha (1995). The nomenclature adopted was that of Roper et al. (1984) and Whitehead et al. (1986).

The catch data were standardised at 9,000 hooks and $10 \mathrm{~km}$ of gill net, taking into consideration the average amount of the two gears used per boat each day, as obtained from interviews.

In order to analyse the catches of both fishing gears in terms of the percentage of occurrence of each species, the species occurrence index (So) was used, expressed by the following equation:

$$
\text { So }=\frac{n_{i}}{N} \times 100
$$

where:

$n_{i}$ - number of times each species was caught by each fishing gear;

$N$ - total number of fishing trials per gear.

Four classes of the species occurrence index $(\mathrm{So})$ were used:

$R$ - rare species - So $<25 \%$;

$U$ - uncommon species - $25 \% \leq$ So $<50 \%$;

$C$ - common species - $50 \% \leq$ So $<75 \%$;

$V$ - very common species - So $\geq 75 \%$.

In order to evaluate any bias caused by the use of a non-commercial boat to deploy gill nets, possible differences in the hake fishing yields were investigated. This comparison was done by means of the $t$ test, which showed no differences $(\mathrm{p}<0.05)$ between our data and those reported on 22 log-book records from the commercial fleet that was operating at the same time and area. Further comparisons between gill net and long-line fishing yields were made by means of the Mann-Whitney rank sum test (Fowler and Cohen, 1990). The KolmogorovSmirnov test for two samples was used to compare the length frequency distributions of the hake catches (Siegel and Castellan, 1988).

In order to investigate trends in the quality of hake in relation to soaking time, a two-stage scale was established, based on the state of deterioration of hake:

- Stage 1 (landed) - fish in perfect condition;

- Stage 2 (discarded) - partially or completely deteriorated fish.

\section{RESULTS}

\section{Catch composition}

A total of 35 species was caught during the study, belonging to 3 groups: finfishes, molluscs and crustaceans (Table 3). Among the 32 fish species, a total of 27 families were identified, with the Squalidae family having the highest number of species (3). In terms of commercially valuable species, a total of 21 species were caught (20 fish species and 1 crustacean species).

Overall, the long-lines caught 23 fish species and the gill nets 25 species ( 22 fish, 2 cephalopod and 1 crustacean species). Out of the 32 fish species 13 were caught by both gears, 10 were only caught by long-lines and 9 were exclusive to gill nets (Table 3). 


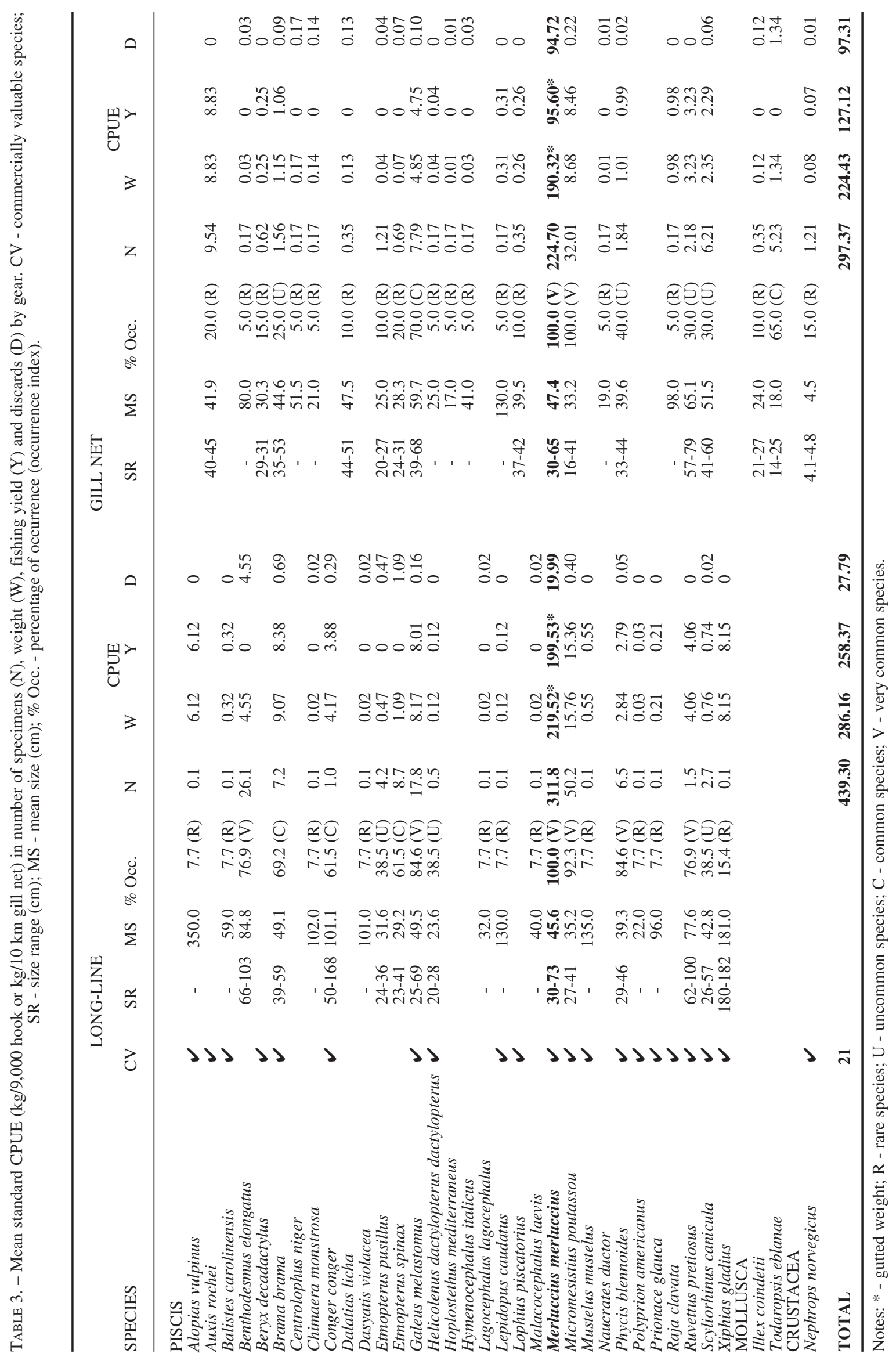


The rare species dominated the catches for both gears (gill nets: $R=68 \%$; long-lines: $R=48 \%$ ) (Table 3 ). This dominance was followed by the very common species $(V=26 \%)$ and the uncommon species $(U=16 \%)$ for long-lines and gill nets respectively. The very common and common species comprised $16 \%$ and $39 \%$ in terms of the total number of species caught by gill nets and longlines respectively.

With regard to commercially valuable species, long-lines caught a higher number of species (16 fish species) than gill nets (13 fish species and 1 crustacean species) (see Table 3 ). Furthermore, common and very common commercial species represented $44 \%(C=$ $13 \%$ and $V=31 \%)$ and $21 \%(C=7 \%$ and $V=14 \%)$ for long-lines and gill nets respectively.

Hake dominated the catches for the two set gears (Table 3) both in terms of weight (77\% and $85 \%$ for long-lines and gill nets respectively) and number of specimens (71\% and $76 \%$ respectively). For the long-lines, Micromesistius poutassou, Galeus melastomus, Brama brama, Benthodesmus elongatus, Etmopterus spinax and Xiphias glaudius also contributed substantially to catches. In the case of gill nets, Auxis rochei, Micromesistius poutassou, Scyliorhinus canicula and Galeus melastomus were also well represented.

\section{Catch size composition}

The long-lines generally caught individuals with higher mean sizes than gill nets (Table 3). The exceptions were Helicolenus dactylopterus dactylopterus, Merluccius merluccius and Scyliorhinus canicula. The size ranges of the long-lines catches were also larger than those obtained for the gill nets.

\section{Hake size frequency distribution}

The size frequency distributions of hake caught by the two gears were very similar (Fig. 2), with a length range of 30 to $73 \mathrm{~cm}$ total length (TL) for long lines and from 30 to $65 \mathrm{~cm}$ TL for gill nets, both above the minimum landing size for this species $(27 \mathrm{~cm} \mathrm{TL})$.

The mean total length was $45.6 \mathrm{~cm}(\mathrm{n}=4,400$; S.D. $=4.89)$ and $47.4 \mathrm{~cm}(\mathrm{n}=1,200 ;$ S.D. $=5.23)$ for long-lines and gill nets respectively. The Kolmogorov-Smirnov test showed statistically significant differences between the two catch size frequency distributions, with a confidence level of $99 \%(D$ $=0.2229>D_{5600}=0.0531$ ).

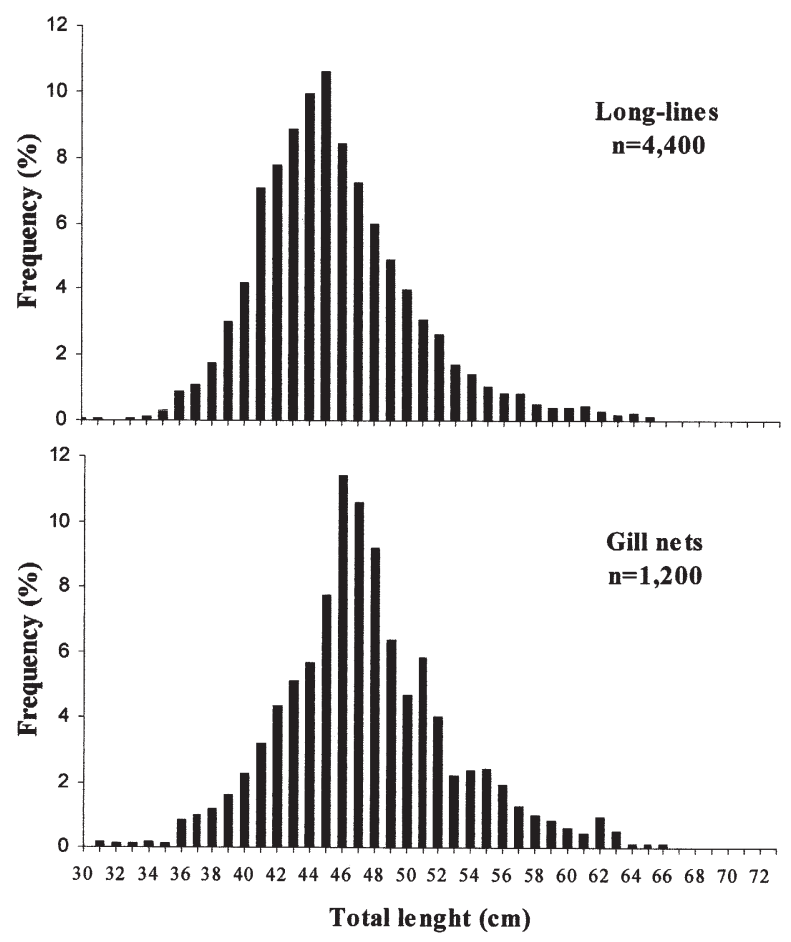

FIG. 2. - Hake size frequency distribution for long-lines and gill nets.

\section{Fishing yield and discards}

The long-line fishing yields per boat day (all species) were significantly higher than that of the gill nets $(T=309.00 ; P=0.001)$. The mean standard total yield was $258.37 \mathrm{~kg}$ (90\% of total catch) and $127.12 \mathrm{~kg}$ (57\% of total catch) for long-lines and gill nets respectively. Furthermore, the hake yield was $199.53 \mathrm{~kg}(70 \%$ of total catch and $77 \%$ of total yield) and $95.60 \mathrm{~kg}$ (43\% of total catch and $75 \%$ of total yield) for long-lines and gill nets respectively. The by-catch represented $23 \%$ and $15 \%$ of the catch in weight for long-lines and gill nets respectively (Table 3).

With the exception for hake, discards were mainly composed of non-commercial species (Table 3). The discards from long-lines were much lower than those from gill nets, $10 \%$ and $43 \%$ respectively. Hake discards represented $7 \%$ of the long-lines total catch and $42 \%$ of the gill nets total catch (Fig. 3). Most hake discards were due to fish deterioration during soak time, which was mainly caused by opportunistic scavenger crustaceans.

The hake quality revealed a marked decreasing trend with gill net soak time. As shown in Figure 4, after 7 hours of soak time $77 \%$ of the hake caught was in good condition, but after 12 hours this percentage decreased to $35 \%$. 
Gill nets

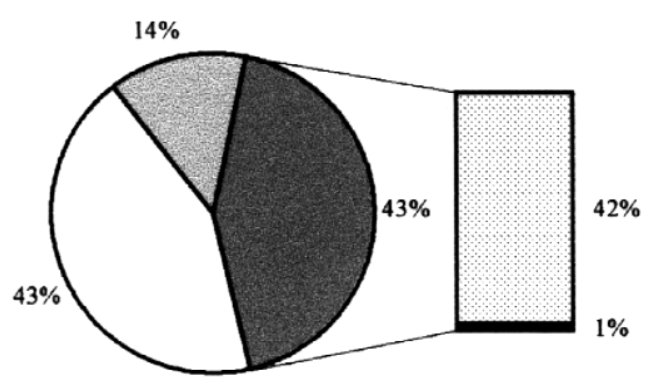

Long-lines

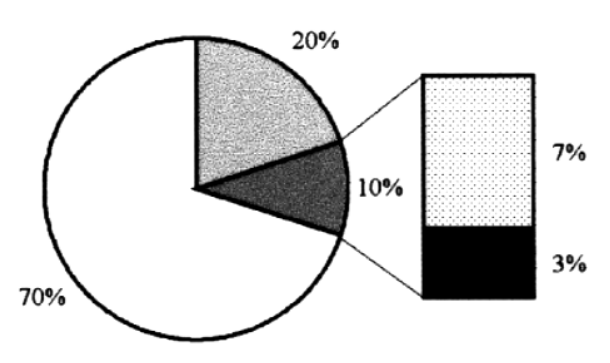

口 Hake yield

口Other commercial species yield

Q Hake discards

Other discards

FIG. 3. - Relative proportion in weight of the different components of the catch by set gear.

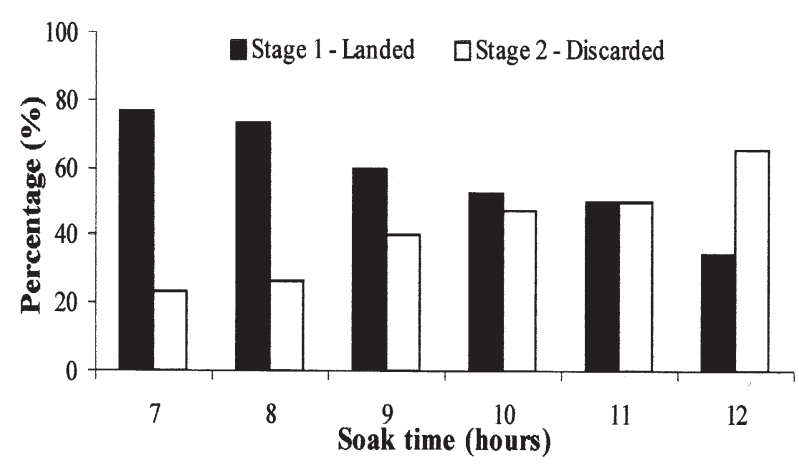

FIG. 4. - Quality of hake related to gill net soak time. Stage 1 - good condition (fish landed); Stage 2 - deteriorated (fish discarded).

\section{DISCUSSION}

\section{Catch composition}

The catches from both set gears used in this study showed a similar species composition. The main differences were primarily due to some pelagic species that were occasionally caught during gear retrieval (e.g. Alopias vulpinus, Xiphias gladius and Auxis rochei). During a long-line selectivity study in the same area, Erzini et al. (2000) reported basically the same species composition, where the main differences in the catch were due to some opportunistic pelagic species caught during gear retrieval.

The analyses of the catch composition showed that the long-line is a much more species-selective fishing gear than the gill net. Furthermore, the catches of commercially valuable fish species are more relevant in long-lines. These aspects are worthy of note and should be taken into consideration while managing this hake fishery.

\section{Catch size composition}

Our results showed that in general gill nets catch each species within a smaller size range, suggesting that they are more size-selective than long-lines. This low size selectivity of long-lines compared to gill nets was also observed by Erzini et al. (1996, 2000). The exceptions to this (Merluccius merluccius, Scyliorhinus canicula and Helicolenus dactylopterus dactylopterus) are explained by the fact that these species are easily entangled.

\section{Hake size frequency distribution}

The size frequency distributions obtained in this study were similar to those reported by Erzini et al. (2000) for the same area. Hake caught in this fishery are of a large size, with no illegal sized fish (under $27 \mathrm{~cm} \mathrm{TL}$ ) caught during the period of study. This is probably related to water depth in the "Beirinha" area (over $500 \mathrm{~m}$ depth) and to the fact that there are depth-related differences in size among hake species, with larger fish found in deeper water (Pitcher and Alheit, 1995). This theoretical assumption has also been suggested by Erzini et al. (2001) for Merluccius merluccius off the coast of the Algarve, and was confirmed by studies for the same area that have been carried out by IPIMAR (Cardador, 1995; Sá, 1999). The depth-related demographic structure of hake populations (Agnew, 1989; Cardador, 1995; Recasens et al., 1998), with deep-water acting as a refuge for part of the adult component, is according to Erzini et al. (2000) probably an important factor contributing to the persistence of hake stocks despite the strong fishing pressure. 


\section{Fishing yield and discards}

Discards of non-commercial species can be considered negligible for these set gears, since they amount for less than $3 \%$ of the total catch in weight. The amount of hake discarded by the long-liners $(7 \%)$ is less than that discarded by gill nets $(42 \%)$. This difference is related to how these two set gears operate while fishing, since hake remain alive for a much longer period when hooked than when caught by gill nets. In addition, a direct relation was found between gill net soak time and hake deterioration.

However, the high percentage of hake discards found for gill nets is much less than that reported for the trawl fisheries in the Algarve. In fact, Borges et al. (1997) found that hake discards from the crustacean and fish trawl fisheries in the Algarve represented 50 to $91 \%$ of the total catch. Nevertheless, according to DGPA (2000) hake landings from trawlers represent only $32 \%$ of the total hake landings in the region.

The differences in fishing yields obtained in this study between the two set gears are mainly due to hake and some occasional pelagic species. However, due to the reasons explained above, hake is the species that most contributed to this fact. With regard to long-line efficiency, the value obtained in this study (3.48 fish/100 hooks) was slightly higher than those reported by Erzini et al. (2000) for the Algarve coast (2.92 fish/100 hooks) and the Cantabrian Sea (3.10 fish/100 hooks).

\section{Fishery management measures}

During the last decade there has been considerable pressure from fishermen to ban gill netting from traditional long-line fishing grounds, and specifically from hake fishing grounds. The results of this study led to the banning of gill net gears from a certain area, since when compared to long-lines they showed: (i) a lower percentage of hake catches and yield, (ii) a lower quality of the fished product and (iii) a higher percentage of discards. This ban was implemented through the establishment of a closed area within the "Beirinha" zone in 1998 and its enlargement in 1999. Furthermore, the amount of discards due to gill netting could be reduced to a much lower level, by setting the limit of gill net soaking time to a maximum of 8 hours, instead of the 12 hours currently allowed. These findings will help to improve the management and conservation of this valuable hake fishery.

\section{ACKNOWLEDGEMENTS}

Thanks are due to Manuela Soares, Teresa Pina and the staff of the Centro Regional de Investigação Pesqueira do Sul (CRIPSul) for collecting the data, and the crews of "RV DONAX" and "TODOS IRMÃOS" for their skilful handling of the set gears and catches. The authors would like to thank the EU for supporting this study (DG XIV Study Contract No. 97/0064). Sincere thanks are also due to the anonymous referees, whose suggestions greatly improved the manuscript.

\section{REFERENCES}

Agnew, D.J. - 1989. The distribution and biology of hake (Merluccius merluccius) subject to the Northern Ireland spring fishery. ICES-CM-1989/G:58, $11 \mathrm{pp}$.

Albuquerque, R.M. - 1956. Peixes de Portugal e Ilhas adjacentes. Chaves para a sua determinação. Port. Acta Biológica, B (5), 1164 pp.

Aldebert, Y. and C. Carries. - 1988. Problèmes d'exploitation du merlu dans le Golfe du Lion. FAO Rapp. Pêches, 395: 87-91.

Aldebert, Y., L. Recasens and J. Lleonart. - 1993. Analysis of gear interactions in a hake fishery: The case of the Gulf of Lions (NW Mediterranean). Sci. Mar., 57: 207-217.

Alheit , J. and T.J. Pitcher. - 1995. Hake: Biology, Fisheries and Markets. Fish and Fisheries Series No. 15. Chapman \& Hall, London.

Anon. - 1998. Selectivité des filets cales en Mediterranée. Rapport final EU Project 95/C/76/12 - SELMED, 99 pp.

Borges, T.C., L. Bentes, M. Castro, M.E. Costa, K. Erzini, J. Gomes, J.M.S. Gonçalves, P.G. Lino, C. Pais and J. Ribeiro. 1997. Studies of the discards of commercial fisheries from the south coast of Portugal. Final Report EU Study Contract No. 95/081, 30 pp.

Brabant, J.C., B. Fontaine, J.P. George, F. Jacqueline, S. Mortreux and J. Sacchi. - 1994. Selectivity of gill nets in the North Sea, English Channel and Bay of Biscay. Periodic Report EU AIR2 Project CT93/1122, 32 pp.

Cardador, F. - 1995. Distribuição e abundância de pescada (Merluccius merluccius) na área de Vila Real de Santo António. Relat. Cient. Téc. Inst. Inv. Pescas Mar, No. 10, 17 pp.

Cardénas, E., B. Villamor and P. Pereda. - 1987. Description of the Spanish long-liner fishery in Division VIIIa, b. ICES C.M. $1987 / G, 21 \mathrm{pp}$.

Casey, J. and J. Pereiro. - 1995. European hake (M. merluccius) in the North-east Atlantic. In: J. Alheit and T.J. Pitcher (eds.), Hake: Biology, Fisheries and Markets, pp. 125-147. Fish and Fisheries Series No. 15, Chapman \& Hall, London.

DGPA. - 2000. Datapescas - Difusão. Ministério da Agricultura, Desenvolvimento Rural e Pescas, No. 43, 12 pp.

Erzini, K., M.N. Santos, C.C. Monteiro, J. Gonçalves, L. Bentes and P.G. Lino. - 1996. Comparison of monofilament gillnet and small hook longline selectivity in a multispecies artisanal fishery in the Algarve, southern Portugal. Naga, 19: 29-32.

Erzini, K., E. Puente, L. Arregui, L. Bentes, M. Castro, J.M.S. Gonçalves, P.G. Lino, J. Ribeiro, J.P. Santiago and F. Sousa. 2000. Hake semi-pelagic long-line selectivity and evaluation of selectivity models for hook and line gear. Final Report EU Study Contract No. 96/062, 190 pp.

Erzini, K., J.M.S. Gonçalves, L. Bentes, P.G. Lino and J. Ribeiro. - 2001. The hake deepwater semi-pelagic ("pedra-bola") longline fishery in the Algarve (southern Portugal). Fish. Res., 51: $327-336$

FAO. - 1997. Review of the state of world fishery resources: Marine fisheries. 2 - Northeast Atlantic (FAO Statistical Area 27). FAO Fish. Circ. No. 920 FIRM/C920, 10 pp.

Fowler, J. and L. Cohen. - 1990. Practical Statistics for Field Biol- 
ogy. Open University Press, Philadelphia.

Huse, I., S. Lokkeborg and A.V. Soldal. - 1996. Effects of fishing strategy on relative selectivity in trawls, longline and gillnets. ICES CM 1996/B:23, 21 pp.

Huse, I. A.C. Gundersen and K.H. Nedreaas. - 1999. Relative selectivity of Greenland halibut (Reinhardtius hippoglossoides, Walbaum) by trawls, longlines and gillnets. Fish. Res., 44: 75-93.

Huse, I., S. Løkkeborg and A.V. Soldal. - 2000. Relative selectivity in trawl, longline and gillnet fisheries for cod and haddock. ICES J. Mar. Sci., 57: 1271-1282.

ICES. - 2001. Report of the working group on the assessment of southern shelf demersal stocks. ICES-CM-2001/ACFM:05, s/p.

Martin, P. - 1991. La pesca en Cataluña y Valencia (NO Mediterráneo). Análisis de las series históricas de captura y esfuerzo. Inf. Téc. Sci. Mar., 162: 1-43.

Martos, A.R. and L.F. Peralta. - 1995. Biology and fisheries of North-west African hakes (M. merluccius, M. senegalensis and M. polli). In: J. Alheit and T.J. Pitcher (eds.), Hake: Biology, Fisheries and Markets, pp. 89-124. Fish and Fisheries Series No. 15, Chapman \& Hall, London.

Moreira, C.D. - 1987. Populações Marítimas em Portugal. Universidade Técnica de Lisboa. Lisboa. 558 pp.

Nedreaas, K., A.V. Soldal and A. Bjordal. - 1993. Performance and biological implications of a multi-gear fishery for Greenland halibut (Reinhardtius hippoglossoides). NAFO Sci. Counc. Rep. Doc., No. 118, 15 pp.

Oliver, P.A. and E. Massuti. - 1995. Biology and fisheries of western Mediterranean hake (M. merluccius). In: J. Alheit and T.J. Pitcher (eds.), Hake: Biology, Fisheries and Markets, pp. 181202. Fish and Fisheries Series No. 15, Chapman \& Hall, London.

Papaconstantinou, C. and K.I. Stergiou. - 1995. Biology and fisheries of eastern Mediterranean hake (M. merluccius). In: J. Alheit and T.J. Pitcher (eds.), Hake: Biology, Fisheries and Markets, pp. 149-180. Fish and Fisheries Series No. 15, Chapman \& Hall, London.

Pitcher, T.J. and J. Alheit. - 1995. What makes a hake? A review of the critical biological features that sustain global hake fisheries.
In: J. Alheit and T.J. Pitcher (eds.), Hake: Biology, Fisheries and Markets, pp. 1-14. Fish and Fisheries Series No. 15, Chapman \& Hall, London.

Recasens, L., A. Lombarte, B. Morales-Nin and G.J. Torres. - 1998. Spatio-temporal variation in the population structure of the European hake in the NW Mediterranean. J. Fish Biol., 53: 387-401.

Roper, C.F.E., M.J. Sweeney and C.E. Neuen. - 1984. FAO Species Catalogue. Cephalopods of the World. An annotated and illustrated catalogue of species of interest to fisheries. FAO Fish. Syn., 125, Vol.3, 277 pp.

Sá, R.S.B. - 1999. Contribuição para o estudo da selectividade das redes de emalhar de um pano fundeadas para a pescada (Merluccius merluccius, Linnaeus, 1758) no Sotavento Algarvio. Relatório de Estágio de Licenciatura em Biologia Marinha e Pescas. Universidade do Algarve, Faro, $65 \mathrm{pp}$.

Saldanha, L. - 1995. Fauna Submarina Atlântica, Portugal Continental, Açores e Madeira. Publicações Europa-América, Lisboa.

Sanches, J.G. - 1992. Guia para identificação do pescado de Portugal submetido a tamanho mínimo de captura. Publicações Avulsas do INIP, No. $18,272 \mathrm{pp}$

Siegel, S. and N.J. Castellan. - 1988. Non-Parametric Statistics for the Behavioural Sciences. Statistics Series, $2^{\text {nd }}$ Edition, McGraw-Hill, New York.

Sousa, F., E. Isidro and K. Erzini. - 1999. Semi-pelagic longline selectivity for two demersal species from the Azores: the black spot sea bream (Pagellus bogaraveo) and the bluemouth rock fish (Helicolenus dactylopterus dactylopterus). Fish. Res., 41: 25-35.

Walsh, S.J. - 1997. Performance of mobile and static gears used in single and multi-species resources surveys: A review. ICES CM 1997/W:2, $22 \mathrm{pp}$

Whitehead, P.J.P., M.-L. Bauchot, J.-C. Hureau, J. Nielsen and E. Tortonese (Eds.). - 1986. Fishes of the North-eastern Atlantic and the Mediterranean. UNESCO (Vols. I, II, III), Paris.

Scient. ed.: P. Sánchez 